\title{
Observations on the flight pattern of some Phlaeothripidae (Thysanoptera) species by using suction trap in Hungary
}

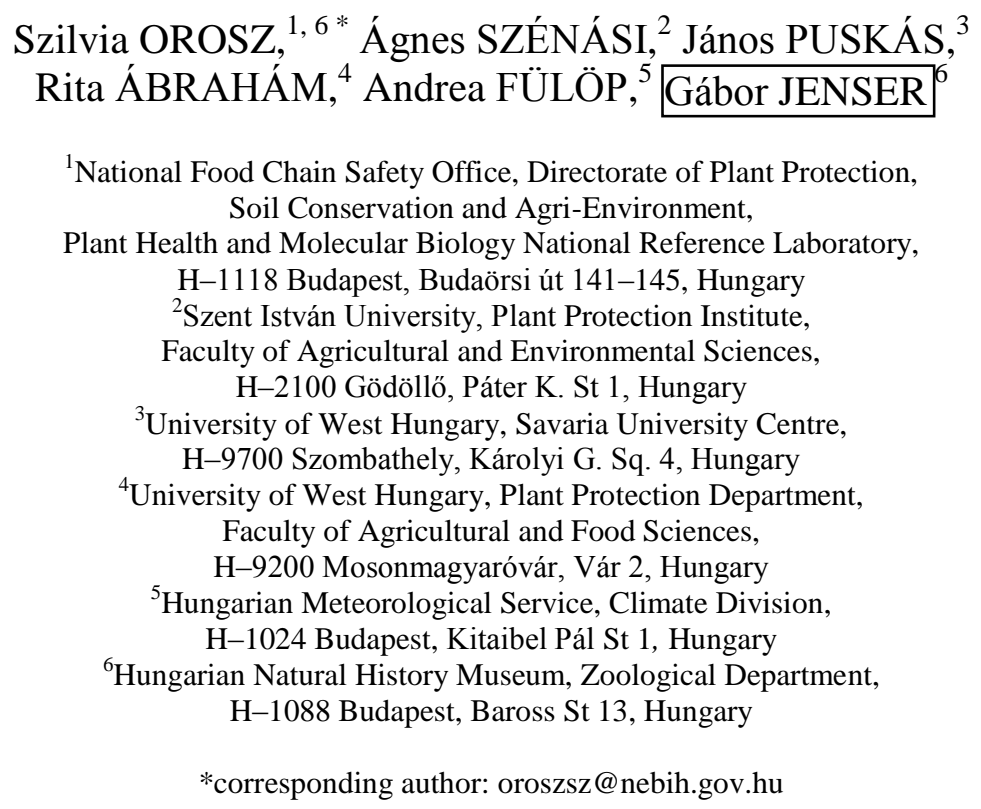

Manuscript received Jan. 20, 2016; revised Febr. 12, 2016; Accepted March 12, 2016

Abstract: In this study, the seasonal flight activity of the Phlaeothripidae (Thysanoptera) species was studied by using suction trap, in South-East Hungary, in the years 2000 and 2004 from April to October. The flight period of two dominant species, namely Haplothrips angusticornis Priesner and Haplothrips aculeatus Fabricius (Thysanoptera: Phlaeothripidae), was observed in high number in Europe. Also, it was the first record of mass flight observation of $H$. angusticornis. In addition, the effect of meteorological factors, such as temperature, sunshine duration, relative humidity, air pressure, and their influences, were evaluated.

Keywords: suction trap, mass flight, Phlaeothripidae, Haplothrips angusticornis, Haplothrips aculeatus 


\section{Introduction}

Thysanoptera is one of the most migratory insect orders because its measured air density could be the highest among the other insect orders. Most winged species have a flight period lasting a few weeks each year. Within this period, some thrips fly on most days, but there are usually a few days when sudden mass flights occur [1]. In Europe and Central Asia, the most noticeable mass flights occur in the case of cereal and grass thrips, such as Limothrips cerealium Haliday, Limothrips denticornis Haliday, and Chirothrips manicatus Haliday (Thysanoptera: Thripidae), when they leave ripening crops to fly towards other host plants at the end of the growing season [2]. Mass flights occur sporadically within the flight period and in many species are reputedly associated with thundery weather. Indeed, in many parts of Europe, thrips are called as "Thunder Flies" or "Storm Flies" as right before storm or thunder their presence in the air increases to a very high number [3]. It is remarkable that the link between thrips and thunder is current in the common names used in so many countries and dates back at least 150 years [4]. However, [2] showed that the occurrence of mass flights of cereal thrips in Germany depended to a greater extent on temperature than on atmospheric pressure or humidity. On the other hand, [1] showed that there was no correlation between thunder and mass flights of thrips in southern England.

Worldwide, the situation of mass flight and migration of Phlaeothripidae species is not clarified yet. According to [1], Tubulifera migration is uncommon in Britain. Glick [5] found that Tubulifera species are more common than Terebrantia in Lousiana (USA) and, by contrast, Haplothrips aculeatus Fabricius (Thysanoptera: Phlaeothripidae) were observed in low numbers in the air in Germany [6].

According to [7], the suitable height for collecting flying Thysanoptera is around $6 \mathrm{~m}$. In an earlier study of [8], a suction trap was used in this height for the autumn mass flight observation of Frankliniella intonsa Trybom (Thysanoptera: Thripidae). [9] used the suction trap at the height of $7.5 \mathrm{~m}$ to determine if suction traps could be useful for monitoring the diversity and flight activity of some Thripidae species. [10] investigated the long-distance dispersal for onion thrips (Thysanoptera: Thripidae). To address these questions, T. tabaci adults were collected using transparent sticky card traps in commercial onion fields at varying heights above the canopy (0.5-6 $\mathrm{m}$ above soil surface) and with trap-equipped unmanned aircrafts (UAVs) flying 50-60 m above onion fields during August sampling periods in 2012 and 2013. Otherwise, there are no data regarding the mass flight of Phlaeothripidae species.

Our current study aims at clarifying the mass flight potentials of Phlaeothripidae species under Hungarian climatic conditions and at determining 
the correlation between the mass flight and meteorological factors such as temperature, sunshine duration, relative humidity, air pressure, and their influences.

\section{Materials and method}

A Rothamsted-type suction trap was operated by the Csongrád County Plant Protection and Soil Conservation Service at Hódmezővásárhely in South-East Hungary in the years 2000-2005 from April to October. It was drawn in 3,000 $\mathrm{m}^{3}$ of air in one hour, at a height of $12 \mathrm{~m}$. The diameter of the collecting tube was 20 $\mathrm{cm}$. The collecting jar was changed daily in the morning at seven o'clock during the experiment. The collected specimens were preserved in $70 \%$ ethanol. Because of the enormous numbers of the collected Phlaeothripidae adults, we selected them in only two years, 2002 and 2004. Each of the studied Phlaeothripidae specimens was mounted according to Schliephake and Klimt [11] for identification.

From the catching data of the examined species, relative catch (RC) data were calculated for each night. The RC is the quotient of the number of individuals caught during a sampling time unit (1 day) per average number of individuals of the same generation falling to the same time unit. In the case of the expected average individual number, the $\mathrm{RC}$ value was 1 . The introduction of $\mathrm{RC}$ enables us to carry out a joint evaluation of materials collected in different years and in different traps [12]. Data on environmental factors, such as temperature, sunshine duration, relative humidity, and air pressure, were arranged into classes according to Sturges' method [13]. The relative catch values were assigned into the classes of the environmental factors belonging to the given day, and then they were summarized and averaged.

All graphics were prepared using Microsoft Excel 2010. The results were characterized by third-degree polynomials. The significance level (the coefficient of determination) was determined according to Manczel [14], by using the following formula:

$$
t=\mathrm{r} / \sqrt{1-\mathrm{r}^{2}} * \sqrt{n-2}
$$

\section{Results}

Species diversity in suction trap for the two years is shown in Table 1.

In the experiments, high numbers of $H$. angusticornis were collected by the suction trap in both years. There were 962 specimens in 2002 and 1,309 specimens in 2004. As for H. aculeatus, in 2002 there were 393 individuals captured by the 
suction trap and by 2004 its number decreased to a very low level, and only 31 specimens were found. Besides these dominant species, only a few numbers of other Phlaeothripidae species were captured in both of the investigated years (Table 1).

Table 1. Individual number of Phlaeothripidae species collected by suction trap (Hódmezővásárhely, 2002 and 2004)

\begin{tabular}{lcc}
\hline Species & No of specimens (2002) & No of specimens (2004) \\
\hline $\begin{array}{l}\text { Haplotrips angusticornis } \\
\text { Priesner 1921 }\end{array}$ & 962 & 1,309 \\
$\begin{array}{l}\text { Haplothrips aculatus } \\
\text { Fabricius 1803 }\end{array}$ & 393 & 31 \\
$\begin{array}{l}\text { Haplothrips hukkineni } \\
\text { Priesner 1950 }\end{array}$ & 0 & 1 \\
$\begin{array}{l}\text { Haplothrips leucanthemi } \\
\text { Schrank 1781 }\end{array}$ & 2 & 1 \\
$\begin{array}{l}\text { Hoplothrips semicaecus } \\
\text { Uzel 1895 }\end{array}$ & 0 & 2 \\
$\begin{array}{l}\text { Bolothrips bicolor } \\
\text { Heeger 1852 } \\
\text { Liothrips setinodes } \\
\text { Reuter 1880 }\end{array}$ & 1 & 0 \\
\hline
\end{tabular}

The effect of meteorological elements for the mass flight of $H$. angusticornis was evaluated. Regarding the influence of the minimum, maximum, and daily mean temperatures, the higher temperature caused higher numbers of migrating specimens, i.e. $19^{\circ} \mathrm{C}$ minimum (Fig. 1), $29{ }^{\circ} \mathrm{C}$ maximum (Fig. 2), and $23{ }^{\circ} \mathrm{C}$ mean temperature (Fig. 3). Concerning the effect of sunshine duration, the more sunny hours had positive influence on the migration of $\mathrm{H}$. angusticornis; in the case of 12 hours/day, the flight was maximum, and they did not fly at night (Fig. 4). The optimal level of relative humidity for the collected individual numbers was about $62 \%$ (Fig. 5). Higher level of relative humidity caused negative effect on the mass flight and migration. The effect of air pressure brought about very contradictory results (Fig. 6) because when the pressure was higher than $1000 \mathrm{hPa}$ the number of migrating specimens steadily declined until $1008 \mathrm{hPa}$, and then started again to increase above this level. 


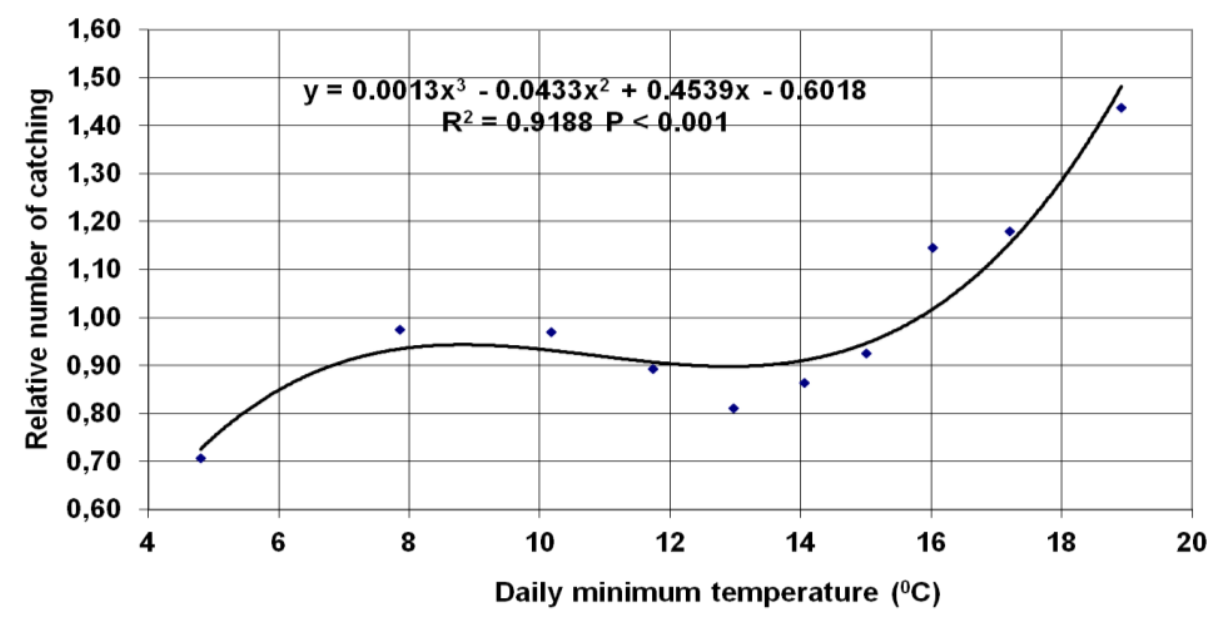

Figure 1. Catching results of Haplotrips angusticornis by the suction trap depending on the daily minimum temperature (Hódmezővásárhely, 2002 and 2004)

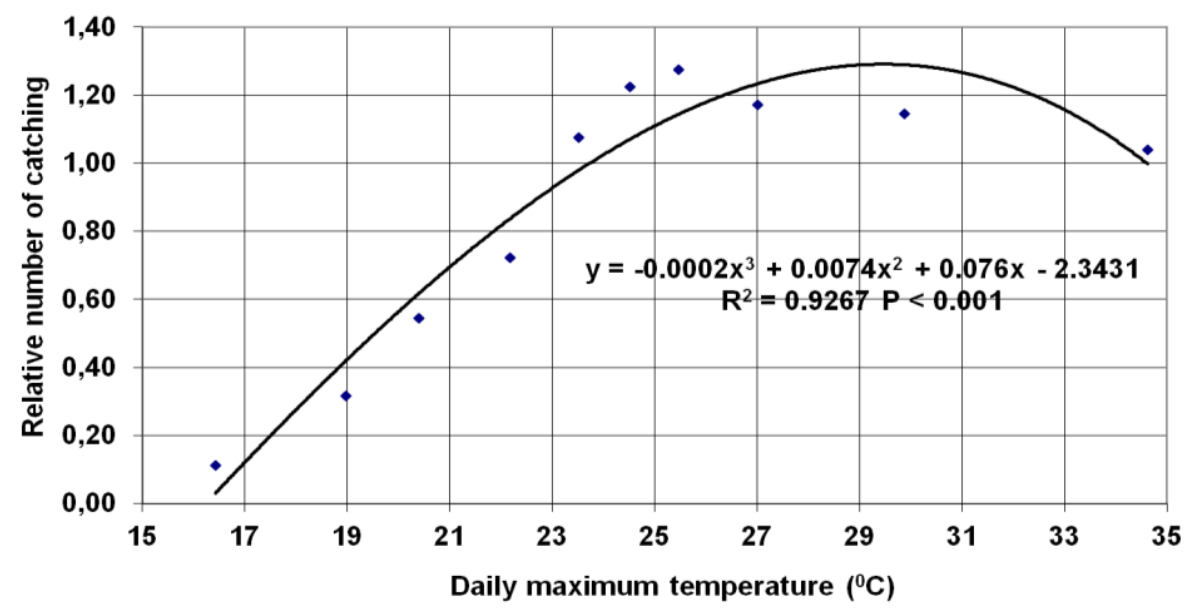

Figure 2. Catching results of Haplotrips angusticornis by the suction trap depending on the daily maximum temperature (Hódmezővásárhely, 2002 and 2004) 


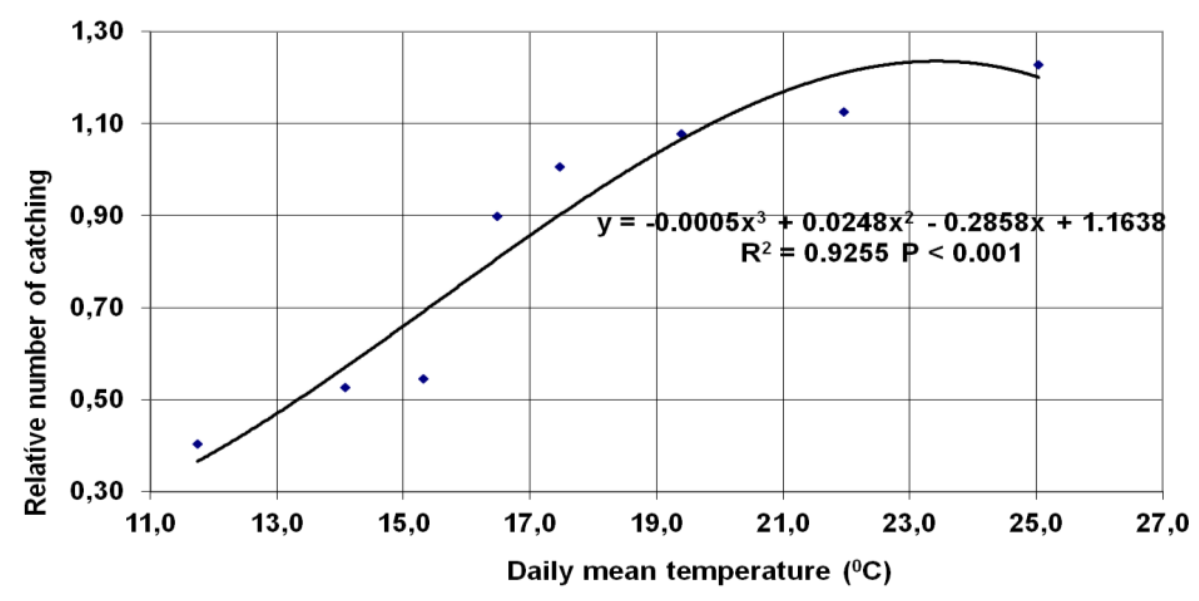

Figure 3. Catching results of Haplotrips angusticornis by the suction trap depending on the daily mean temperature (Hódmezővásárhely, 2002 and 2004)

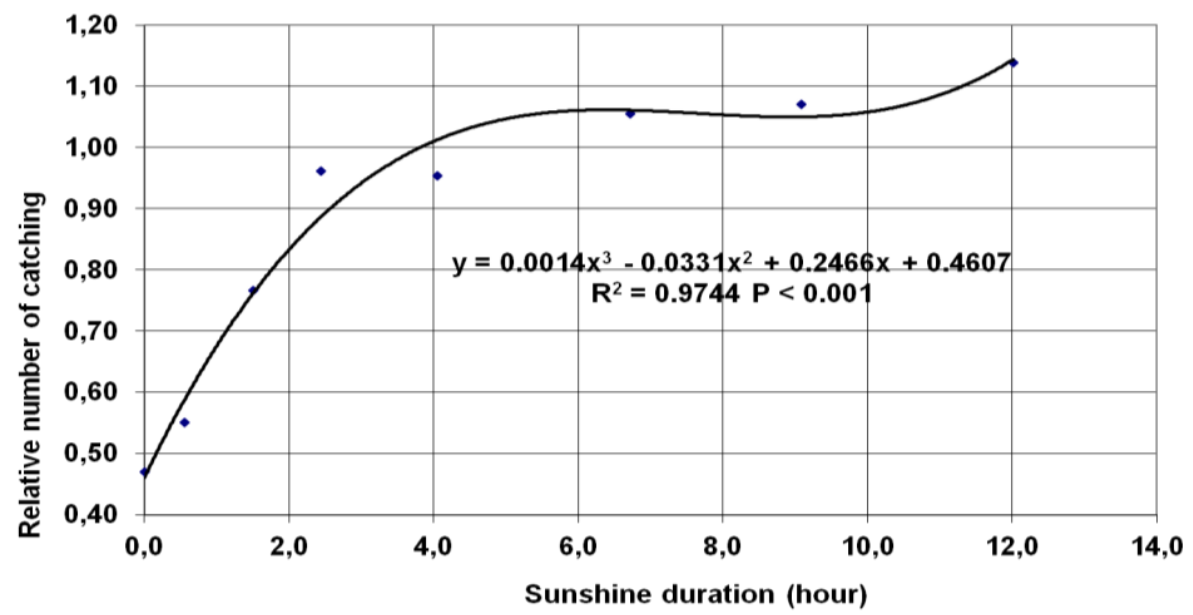

Figure 4. Catching results of Haplotrips angusticornis by the suction trap depending on the sunshine duration (Hódmezővásárhely, 2002 and 2004) 


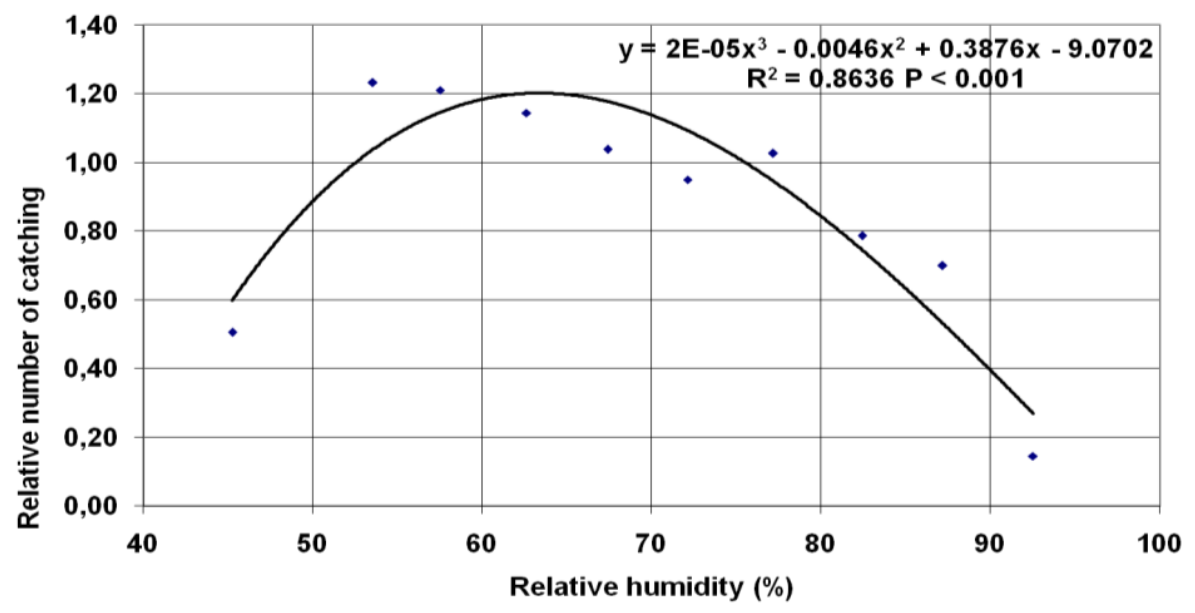

Figure 5. Catching results of Haplotrips angusticornis by the suction trap depending on the relative humidity (Hódmezővásárhely, 2002 and 2004)

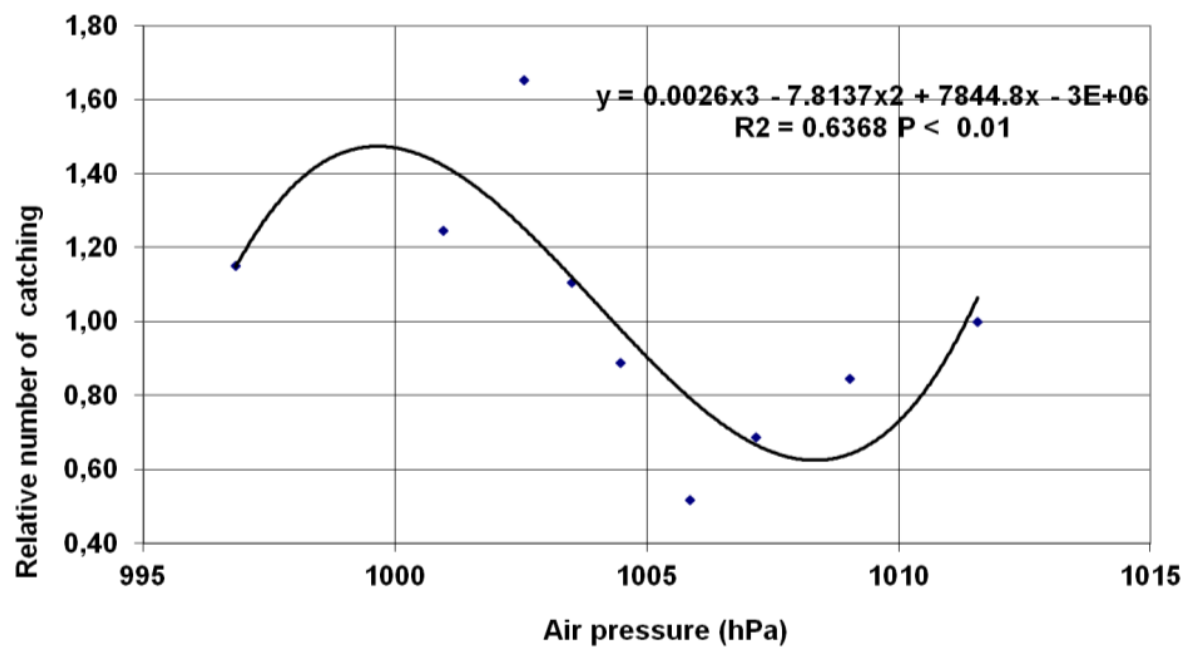

Figure 6. Catching results of Haplotrips angusticornis by the suction trap depending on the air pressure (Hódmezővásárhely, 2002 and 2004)

H. angusticornis migrated from April to late September in both years, while H. aculeatus started to migrate from late May to early November in 2002. The catching number of $H$. angusticornis was the highest on 26 May 2002 and on 22 
July 2004. The mass flight of this species was observed in 2002 from mid-May to late June and in 2004 at the end of July (Fig. 7, 8).

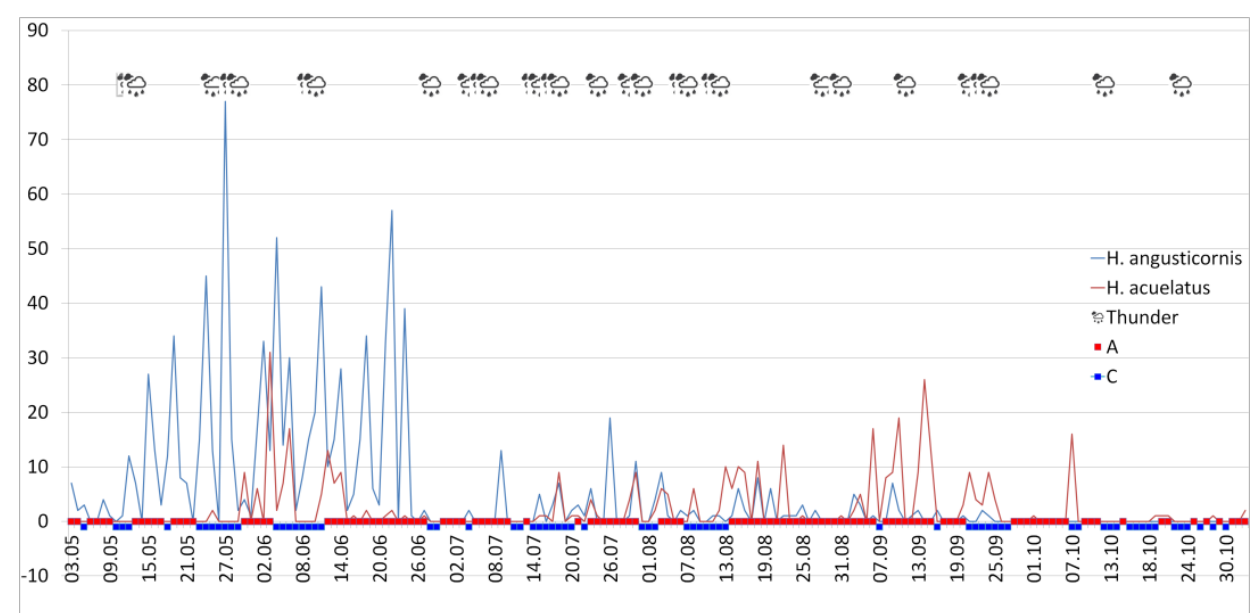

Figure 7. Seasonal flight activity of $H$. angusticornis and $H$. aculeatus observed by the suction trap in 2002 (A = anticyclonic climatic conditions; $\mathrm{C}=$ cyclonic climatic conditions) (Hódmezővásárhely, 2002) (On the $\mathrm{X}$ axis of the graph, together with the date, the changing of cyclonic and anticyclonic periods are shown, according to the data of the Hungarian Meteorological Service, regarding the studied area. On the top part of this graph, there are small cloud signs, referring to the stormy days.)

In 2002, the anticyclonic climatic conditions were prevalent. During the investigated period of this year, there were 67 days under cyclonic and 117 days under anticyclonic climatic conditions (Fig. 7). Probably, this circumstance could also have a role in the continuous migration of both species. According to our experiences, the storm or thunder had no direct influence on the numbers of the migrating adults. In 2004, the same situation was observed. According to the data of the Hungarian Meteorological Service, during this whole vegetation period, the anticyclonic climatic condition was also prevalent. The number of migrating $H$. angusticornis was even much higher in July than in the previous investigated year (Table 1, Fig. 8). 


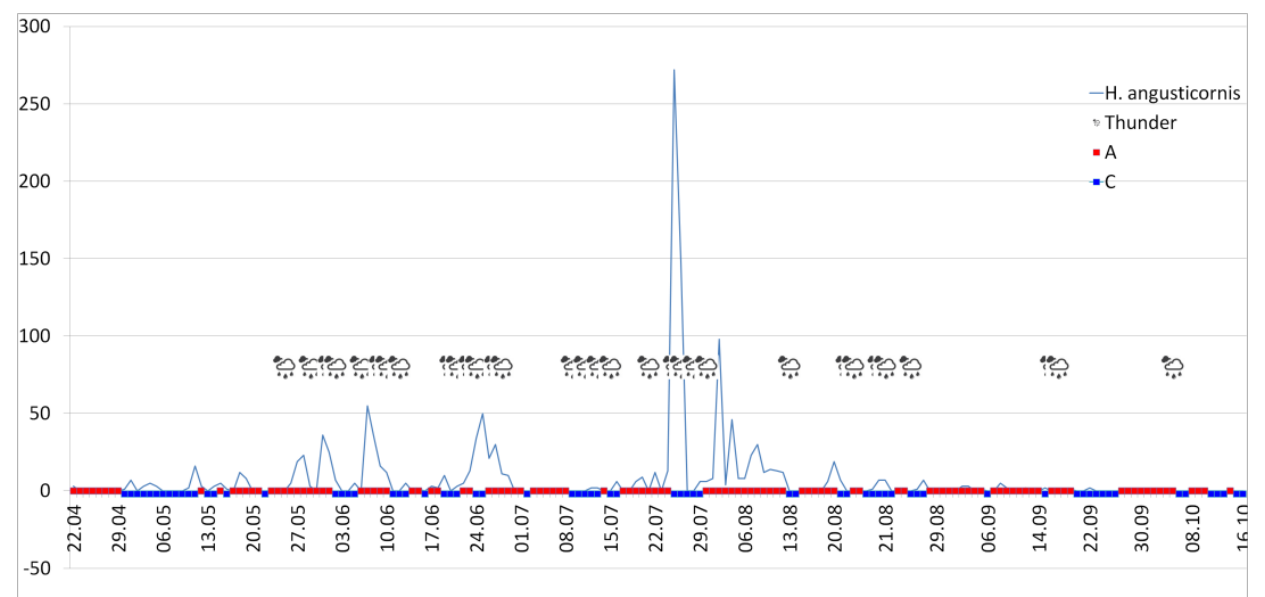

Figure 8. Seasonal flight activity of $H$. angusticornis observed by the suction trap in 2004 ( $\mathrm{A}=$ anticyclonic climatic conditions; $\mathrm{C}=$ cyclonic climatic conditions)

(Hódmezővásárhely, 2004) (On the X axis of the graph, together with the date, the changing of cyclonic and anticyclonic periods are shown, according to the data of the Hungarian Meteorological Service, regarding the studied area. On the top part of this graph, there are small cloud signs referring to the stormy days)

\section{Discussion}

The migration and the mass flight of thrips species depend on the meteorological conditions, the spatial composition of the host plants, and their ripening time [3].

This study is the first report concerning the mass flight of Haplothrips angusticornis. Although this species sporadically occurs in Central and Southern Europe, it is widespread in Hungary [15]. H. angusticornis was primarily found in the flower of weeds belonging to the family Asteraceae (Achillea spp., Anthemis spp., Matricaria spp., etc) [6]. The main cause of the mass flight of this species could be that $H$. angusticornis was breeding in temporary habitats, after which it must migrate to survive on overwintering weed species or in other hidden places. This tendency for species living in temporary habitats could be more migratory than for species from permanent ones. According to [1], cereal and grass-feeding thrips, belonging to the Thripidae suborder, are predominant in mass flight. Though H. angusticornis is neither a cereal nor a grass-feeder species, in 2002 and 2004, they occurred in surprisingly high numbers in the air (Table 1). However, the life 
habits and flight activity of this species still need to be clarified. There is no data available on the biology of $H$. angusticornis.

Haplothrips aculeatus is widely spread in Europe, and also a common species in Hungary [16]. This species is mostly a cereal and grass feeder [1]. It leaves the hibernation sites very late, when the maximum temperature is more than $20{ }^{\circ} \mathrm{C}$ for many days [16]. According to our results, this species started to migrate in late May (Fig. 7). It can migrate continuously during the vegetation period [6]. The migration depends on the host plants' (Poaceae or Asteraceae species) ripening time. In the present study, $H$. aculeatus migrated continuously during the whole vegetation period of 2002 (Fig. 7). [17] indicated that this species was found in higher numbers on Anthemis arvensis L., Erigeron annuus L., Matricaria maritima L., Taraxacum officinale F. H. Wigg, Galinsoga parviflora Cav., Ambrosia artemisiifolia L. (Asteraceae), Medicago sativa L. (Fabaceae), and Amaranthus retroflexus L. (Amaranthaceae). According to [6] and [1], H. aculeatus was observed in low numbers in the air. Our study confirms these experiences because there were 393 and only 31 specimens captured in the air by the suction trap during the whole vegetation period of 2002 and 2004, respectively (Table 1).

According to our data, under anticyclonic meteorological conditions, there is a stronger possibility for an increased number of migrating $H$. angusticornis. The meteorological elements of anticyclonic climatic conditions are the followings: higher temperature, stronger sunshine duration, and higher air pressure. Under cyclonic climatic condition, the meteorological elements are the opposite: lower temperature, less sunshine duration, and lower air pressure. According to [2] and [18], the temperature has the most important effect on the migration of the thrips. As for the influence of the minimum, maximum, and daily mean temperatures, the higher temperature caused the higher numbers of migrating specimens in this study. According to our investigation, the more sunny hours have positive influence on the migration of $\mathrm{H}$. angusticornis (Fig. 4) and the optimal level of relative humidity was about $62 \%$ (Fig. 5). The higher level of relative humidity has a negative effect on the mass flight and migration. The effect of air pressure proved to be very contradictory in this study (Fig. 6). The concrete effect of this element needs to be clarified in the future.

The thunder had no influence on the flight of the studied Haplothrips species. Basically, during the storm or thunder, none of the thrips species could fly [1]. Therefore, the wind can also cause a lower number of migrant Thysanoptera adults.

\section{Acknowledgement}

The research work was supported by the Research Centre of Excellence 9878/3/2016/FEKUT (Szent István University). The authors are thankful to Dr M. 
Bora Kaydan for his suggestions and critical reviewing of the paper and to $\mathrm{Dr}$ László Nowinszky for doing the statistical analysis.

\section{References}

[1] Lewis, T. (1973), Thrips, their biology, ecology and economic importance. Academic Press, London and New York.

[2] Körting, A. (1930), Beitrag zur Kenntnis der Lebensgewohnheitenund der phytopathogenen Bedeutung einiger an Getreide lebender Thysanopteren. Zeitschrift für Angewandte Entomologie 16, 451-512.

[3] Lewis, T. (1964), The weather and mass flight of Thysanoptera. Annals of Applied Biology 53, $165-170$

[4] Kirk, W. D. J. (2004), The link between cereal thrips and thunderstorms. Acta Phytopathologica et Entomologica Hungarica 39, 131-136.

[5] Glick, P. A. (1939), The distribution of insects, spiders and mites in the air. U.S. Department of Agriculture Technical Bulletin 673.

[6] Klimt, von K. (1971), Faunistisch-systematische Studien an ungarischen Phlaeothripiden (Thysanoptera). Folia Entomologica Hungarica 24, 47-66.

[7] Johnson, C. G. (1969), Migration and dispersal of insects by flight. Methuen and Co. Ltd, London.

[8] Jenser, G. (1973), Observation on the autumn mass flight of Frankliniella intonsa Trybom (Thysanoptera: Thripidae). Acta Phytopathologica Academiae Scientiarum Hungaricae 8, 227 230.

[9] Teulon, D. A. J., Penman, D. R. (1996), Thrips (Thysanoptera) seasonal flight activity and infestation of ripe stonefruit in Canterbury, New Zealand. Journal of Economic Entomology 89, 722-734.

[10] Smith, E. A., Fuchs, M., Shields, E. J., Nault, B. A. (2015), Long-distance dispersal potential for onion thrips (Thysanoptera: Thripidae) and Iris yellow spot virus (Bunyaviridae: Tospovirus) in an onion ecosystem. Environmental Entomology 44, 921-930.

[11] Schliephake, G., Klimt, von K. (1979), Thysanoptera, Fransenflüger. VEB Gustav Fischer Verlag, Jena.

[12] Nowinszky, L. (2003), The handbook of light trapping. Savaria University Press.

[13] Odor, P., Iglói, L. (1987), An introduction to the sport's biometry. ÁISH Tudományos Tanácsának Kiadása. Budapest.

[14] Manczel, J. (1983), Using statistical methods in agriculture. Mezőgazdasági Kiadó, Budapest.

[15] Jenser, G. (1982), Thysanoptera. In: Fauna Hungariae. V, 13. Academic Press, Budapest.

[16] Czencz, K. (1983), Study of Thysanoptera living on cereals. Növényvédelem 19, 341-345.

[17] Orosz, Sz. (2012), Investigation of Thysanoptera populations in sweet pepper greenhouses and in their surroundings. PhD dissertation. Szent István University, Gödöllő.

[18] Johansson, E. (1946), Studier och forsook rörande de pa gras och sadesslag levande tripsarnas biologi och skadegörelse. II. Tripsarnas frekvers och spridning i jamförelse med andra sugande insekters samt deras fröskadegörande betydelse. Meddelanden Statens Växtskyddsanstalt 46, $1-59$. 